\title{
Implantation Dermoid Cyst
}

\author{
Gheena Sukumaran ${ }^{1}$, Pratibha Ramani², Abilasha Ramasubramanian ${ }^{3}$, Monika Karunagaran ${ }^{4}$, Hannah Ravikumar ${ }^{5}$
}

${ }^{1}$ Department of Oral Pathology, Saveetha Dental College and Hospitals, Saveetha University, Saveetha Institute of Medical and Technical Sciences, Chennai, Tamilnadu, India. ${ }^{2}$ Department of Oral Pathology, Saveetha Dental College and Hospitals, Saveetha University, Saveetha Institute of Medical and Technical Sciences, Chennai, Tamilnadu, India. ${ }^{3}$ Department of Oral Pathology, Saveetha Dental College and Hospitals, Saveetha University, Saveetha Institute of Medical and Technical Sciences, Chennai, Tamilnadu, India. ${ }^{4}$ Department of Oral Pathology, Saveetha Dental College and Hospitals, Saveetha University, Saveetha Institute of Medical and Technical Sciences, Chennai, Tamilnadu, India. ${ }^{5}$ Department of Oral Pathology, Saveetha Dental College and Hospitals, Saveetha University, Saveetha Institute of Medical and Technical Sciences, Chennai, Tamilnadu, India.

\section{INTRODUCTION}

Dermoid cysts are cystic lesions which are lined by epithelium with associated adnexal structures in the connective tissue or comprising of tissues of ectoderm, mesoderm and endoderm. [1] They constitute 1.6- 6.9\% of all cysts of head and neck and $0.01 \%$ of intra-oral cystic lesions.[2],[3] The dominant site of occurrence is the floor of the mouth, predominantly the submental region, very rarely in other sites. Dermoid cysts are usually treated by enucleation.[4],[5] Enucleation of the entire lesion usually leads to a good prognosis. Malignant transformation of the dermoid cyst has been reported in sites other than the oral cavity.[6],[7] This case report documents an implantation dermoid cyst in the left molar region of a female patient.

\section{PRESENTATION OF CASE}

A 32-year-old female patient presented to the department of Oral Surgery with pain in the left posterior tooth region of the mandible for a duration of 3 months. On intraoral examination, the site showed no obvious evidence of swelling and/or associated discharge of pus or blood. Palpation elicited tenderness in the affected area. Radiological examination revealed a multilocular radiolucent area extending from 41 to 38 region provisionally diagnosed as an odontogenic cyst (Figure 1). The patient underwent enucleation of the cyst and the specimen was subjected to histopathology.

The histopathology report showed odontogenic epithelial lining and connective tissue wall. The epithelial lining is hyperparakeratinised stratified squamous epithelium of about 6-10 cells thick with surface corrugations and palisading of basal cells. The underlying connective tissue wall is composed of mixed inflammatory cell infiltrate predominantly lymphocytes, plasma cells and few neutrophils along with moderate vascularity and areas of haemorrhage. Numerous cholesterol clefts and peripheral resorbing bone in few areas are also evident. The diagnosis was given as Radicular cyst.

At the second visit five months after the enucleation there was no obvious swelling, evidence of pus or blood, however, the patient complained of pain and tenderness in the area. An additional finding was the presence of numerous Fordyce's granules over the left buccal mucosa (Figure 2). An excisional biopsy was performed and the specimen submitted for histopathological evaluation. The submitted specimen was multiple bits the largest measuring $0.4 \mathrm{X} 0.5 \mathrm{cms}$ in size, greyish white in colour and soft in consistency (Figure 3).
Corresponding Author: Dr. Gheena Sukumaran, Department of Oral Pathology, Saveetha Dental College and Hospitals, Saveetha University, Saveetha Institute of Medical and Technical Sciences, Chennai, Tamilnadu, India.

E-mail:gheens@gmail.com

DOI: $10.14260 /$ jemds/2019/871

Financial or Other Competing Interests: None.

How to Cite This Article:

Sukumaran G, Ramani P, Ramasubramanian $A$, et al. Implantation dermoid cyst. J. Evolution Med. Dent. Sci. 2019;8(52):4023-4025,

10.14260/jemds/2019/871

Submission 04-11-2019,

Peer Review 13-12-2019,

Acceptance 19-12-2019,

Published 30-12-2019. 
Histopathological report revealed a hyperparakeratinised stratified squamous epithelium of varying thickness with a connective tissue wall exhibiting sebaceous glands. The underlying dense mature connective tissue stroma also shows evidence of numerous sebaceous glands along with areas of haemorrhage. It was diagnosed as Implantation dermoid cyst taking into account the chance finding of Fordyce's granules in the left buccal mucosa (Figure 4). Post surgically, at recall after three months the patient was asymptomatic.
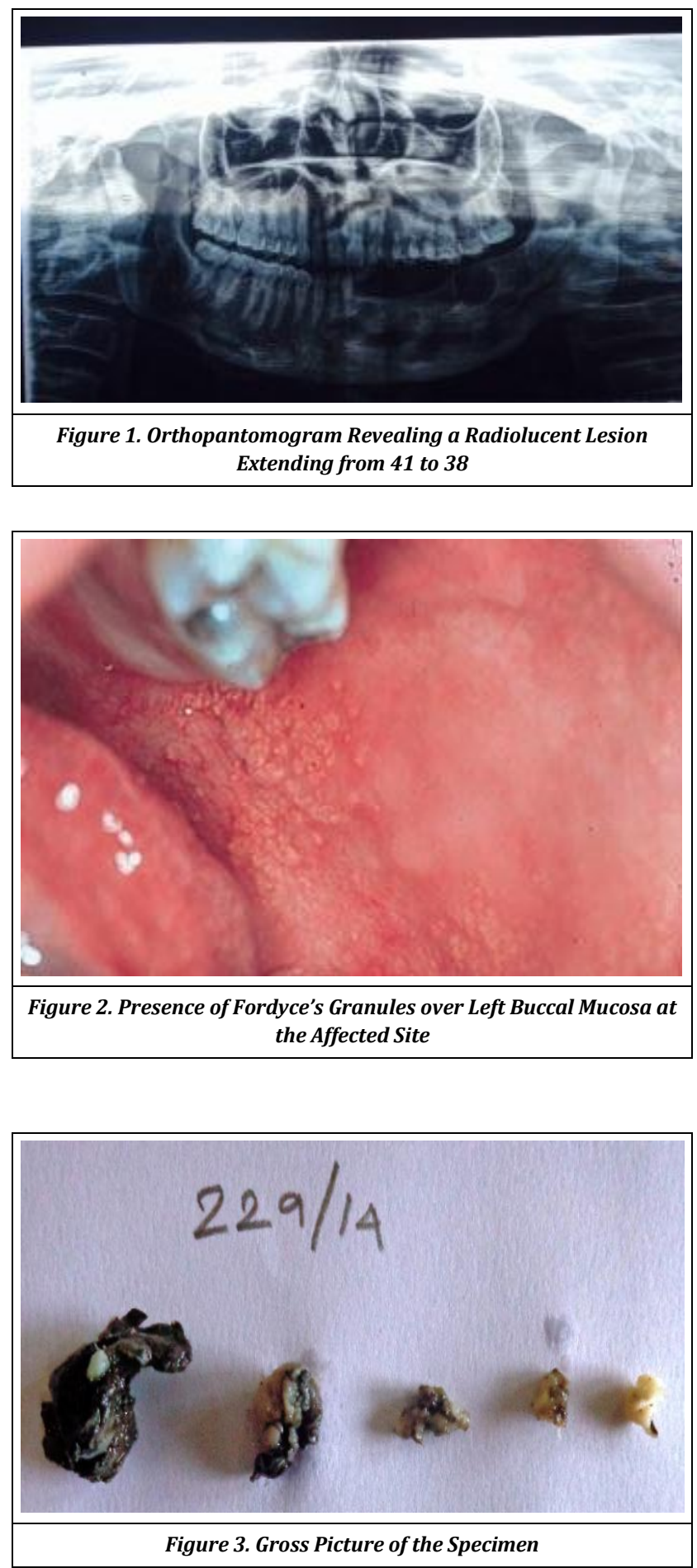

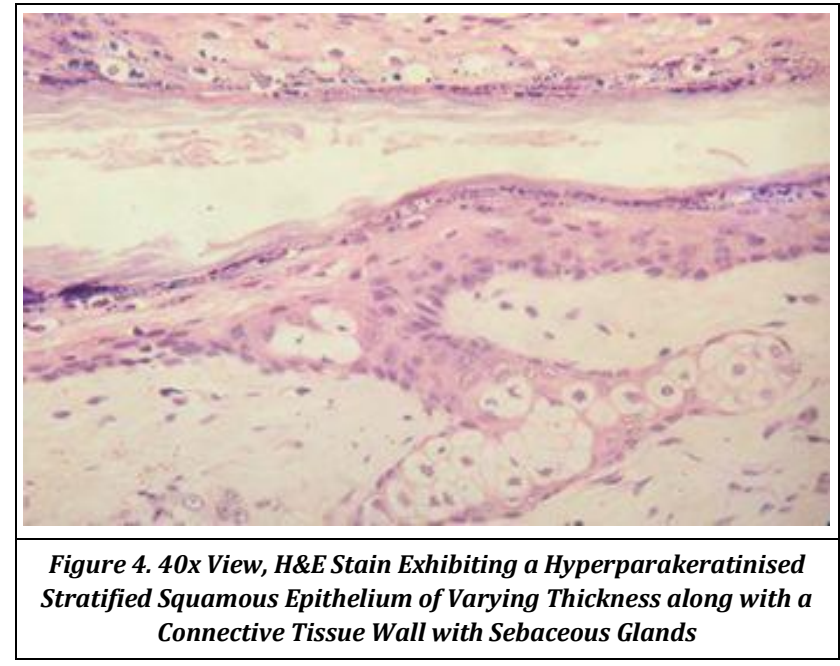

DISCUSSION

Dermoid cysts rarely occur in the oral cavity. Oral dermoid cysts accounts for $1.6 \%$ of all dermoid cysts, and $0.01 \%$ of all oral cysts.[1] In a review of 1459 cases of dermoid cysts, New and Frich observed that only $1.6 \%$ involved the oral cavity and $1 / 4$ th of those occurred in the floor of the mouth. ${ }^{[8]}$ Taylor et al studied 541 dermoid cysts of the head and neck and observed that $6.5 \%$ of them were intraoral.[9] Shore reported only 4 cases of sublingual dermoid cysts in a review of 54,000 surgical specimens.[10] The predominant location in the head and neck region for the occurrence of dermoid cysts is the periorbital site followed by the intra oral site. At the intraoral site, it is observed in the floor of the mouth.[11] Dermoid cyst of the mandible is uncommon and rarely documented in the literature. In the present case the lesion involved the left posterior tooth region of mandible from 41 to 38 . Clinically there was no obvious lesion though Fordyce's granules were observed in the area; radiographically, the orthopantomogram showed evidence of a multilocular radiolucent area in the region.

New and Frich[12] identified this lesion in patients of all ages, however they were found to occur predominantly between 15 to 35 years of age.[1],[12],[13] Walstad et al[14] observed a general trend of occurrence and between 20-30 years of age and to have an equal sex predilection. This is in concordance to several other studies.[1],[12],[13],[15] The case report being discussed fitted the age criteria reported to have the most frequent occurrence.

The pathogenesis of dermoid cyst is unestablished with two plausible theories. The most accepted is the congenital theory, suggesting that the cyst originates from the median pluripotent tissue incorporated during the fusion of the first and second brachial arch. The second theory, the acquired theory, implicates implantation of epithelial cells in deep tissue during intrauterine life secondary to trauma or accident.[3]

Three histological variants of dermoid cyst have been described in literature. [12]

1. The simplest is the Epidermoid cyst with stratified squamous lining epithelium with no accompanying adnexal structures, 
2. The Dermoid cyst with stratified squamous epithelial lining associated with adnexal structures in the fibrous connective tissue wall

3. The complex teratoid cyst with expression of all three germ layers and exhibiting a range of epithelia.

Our case is a true dermoid cyst as manifested by the histopathological features of a hyperparakeratinised stratified squamous epithelium with sebaceous glands in the underlying connective tissue wall. The occurrence of the dermoid cyst at the unusual site, the left posterior region of the mandible, might be due to the implantation of surface epithelial cells into the site supposedly during the previous enucleation. Corroborating this is the evidence of numerous Fordyce's granules in the adjacent buccal mucosa.

The radiological differential diagnosis for the lesion at this site can be a Keratocystic Odontogenic Tumor, Ameloblastoma or an Implantation Epidermoid/Dermoid cyst. The characteristic histopathological features point to a definite diagnosis of implantation dermoid cyst.

\section{CONCLUSIONS}

This case report describes a rare case of Implantation Dermoid Cyst in the left posterior edentulous region of the mandible in a 32-year-old female. The unusual site of occurrence implies the implantation of epithelial cells during the previous enucleation performed at the site. Histopathology is characteristic. The case was treated surgically by excision and there is no recurrence till date. The case is unique because of its site of occurrence and positive evidence of traumatic implantation thus diagnosed as implantation dermoid cyst.

\section{REFERENCES}

[1] Shafer WG, Hine MK, Levy BM. A Textbook of Oral Pathology. $4^{\text {th }}$ edn. Philadelphia: WB Saunders 1974: p. 78-9.
[2] Rajayogeswaran V, Eveson JW. Epidermoid cyst of the buccal mucosa. Oral Surg Oral Med Oral Pathol 1989;67(2):181-4.

[3] Triantafillidou E, Karakasis D, Laskin J. Swelling of the floor of the mouth. J Oral Maxillofac Surg 1989;47(7):7336.

[4] El-Hakim E, Alyamani A. Alternative Surgical approaches for excision of dermoid cyst of the floor of mouth. Int J Oral Maxillofac Surg 2008;37(5):497-9.

[5] Ozan F, Polat HB, Ay S, et al. Epidermoid cyst of the buccal mucosa: a case report. J Contemp Dent Pract 2007;8(3):90-6.

[6] Kramer IR, Pindborg JJ, Shear M. The WHO histological typing of Odontogenic tumours. A commentary on the second edition. Cancer 1992;70(12):2988-94.

[7] Philipsen HP, Reichart PA. Revision of the 1992- edition of the WHO histological typing of Odontogenic tumours. A suggestion. J Oral Pathol Med 2002;31(5):253-8.

[8] Seward GR. Dermoid cyst of the floor of the mouth. Br J Oral Surg 1965;3(1):36-47.

[9] Taylor BW, Erich JB, Dockerty MB. Dermoids of the Head and Neck. Minn Med 1966;49(1):1535-40.

[10] Shore BR. Sublingual epidermoid cyst. Ann Surg 1938:108(2):305-8.

[11] Jadwani S, Misra B, Kallianpur S, et al. Dermoid cyst of the floor of the mouth with abundant hair: a case report. J Maxillofac Oral Surg 2009;8(4):388-9.

[12] New GB, Erich JB. Dermoid cysts of the head and neck. Surg Gynecol Obstet 1937;65:48-56.

[13] Meyer I. Dermoid cysts (dermoids) of the floor of the mouth. Oral Surg Oral Med Oral Pathol 1955;8(11):114964.

[14] Walstad WR, Solomon JM, Schow SR, et al. Midline cystic lesion of the floor of the mouth. J Oral Maxillofac Surg 1998;56(1):70-4.

[15] Gorlin RJ, Goldman HM. Thoma's Oral Pathology. $6^{\text {th }}$ edn. St. Louis: Mosby 1970: p. 463-4. 